\title{
Bank Capital, Financial Stability and Basel Regulation in a Low Interest-Rate Environment *
}

\author{
Margarita Rubio ${ }^{\dagger}$ \\ Fang Yao ${ }^{\ddagger}$ \\ University of Nottingham \\ Reserve Bank of New Zealand
}

December 2019

\begin{abstract}
The current low interest-rate environment poses new challenges to international bank regulation policies. This paper analyzes the role of the Basel regulation in this new context. We study this issue by using a DSGE model with housing and collateral constraints, both on borrowers and banks. Results show that, on the one hand, low interest rates lead to an increase in bank capital, calling for less strict intenational regulatory regimes. On the other hand, this environment encourages more indebtedness of borrowers, calling for a stricter regulation for macroprudential purposes. An optimal analysis of the countercyclical buffer in Basel III regulation reveals that risks to financial stability outweigh the extra accumulation of bank capital. Thus, the countercyclical buffer should be implemented more aggressively in a low interest-rate world.
\end{abstract}

Keywords: Basel regulation, International financial markets, Macroprudential policy, collateral constraint, financial stability

JEL Classification: E32, E44, E58

\footnotetext{
${ }^{*}$ The authors would like to thank Oscar Jorda for his very useful comments and to the participants and discussant of the FMND conference in Paris, the MMF conference in London, the Dynare conference in Lausanne, and the seminars at the University of Nottingham and Nottingham Trent University. The views expressed in this paper are those of the authors and do not necessarily reflect the views of the Reserve Bank of New Zealand. Usual disclaimer applies.

${ }^{\dagger}$ University of Nottingham, University Park, Sir Clive Granger Building, NG7 2RD Nottingham, UK. E-mail. margarita.rubio@nottingham.ac.uk.

${ }^{\ddagger}$ Reserve Bank of New Zealand. 2 The Terrace, Wellington, 6140, New Zealand. E-mail: Fang.Yao@rbnz.govt.nz.
} 
"In recent years important changes in the asset and liability structure of euro area banks took place. They considerably increased their capital and reduced their assets [...] However, a protracted period of ultra-low interest rates poses also a number of risks to financial stability: Low interest rates provide incentives to increase indebtedness, they could lead to a search for yield and compromise the sustainability of the business models of banks and insurance companies." Speech by OeNB Vice Governor Andreas Ittner at the conference jointly organized by SUERF, the OeNB and the Austrian Society for Bank Research "Asset-Liability Management with Ultra-Low Interest Rates," Vienna, 11 March 2015

\section{Introduction}

After the Global Financial Crisis (GFC) in 2008/09, we have learn that it is necessary to have a sound and stable economic and financial environment. In order to promote economic recovery and stabilize the financial sector, some changes to the international financial regulation have been proposed. In this context, a very important package of regulations is the so-called Basel III. Basel III is a comprehensive set of reform measures in banking regulation, supervision and risk management, based on capital requirements. It was developed by the Basel Committee on Banking Supervision (BCBS) at the Bank for International Settlements (BIS), to strengthen the banking sector and achieve financial stability. Policymakers are aware, though, that Basel III implementation can be associated with some short-term costs and long-term benefits. A better capitalized banking system should bring about long-term benefits in terms of financial stability. The estimated marginal reduction in the annual probability of a crisis ranges across studies from 0.03 percentage points to as much as 1.7 percentage points. In the short run, though, higher required bank capital reduces loan growth and thus output. Nevertheless, there is consensus in the literature that the net macroeconomic benefits of capital requirements are positive over a wide range of capital levels (See: e.g. BCBS, 2019, Aikman et al., 2018, Barth and Miller, 2018, Jorda et al., 2017 and Daguer et al., 2016, among others).

Some of the new measures that Basel III introduces are aimed at preventing future crises, creating a sound financial system, in which financial problems will be refrained from spreading to the real economy. Preventive measures acting in this direction are known between researchers and policy-makers as macroprudential policies. However, there are new challenges to the conduct of these macro-financial stabilization policies. One of the major changes in this new international economic environment is a significant decline in the neutral real interest rate. In many advanced economies, estimated long-term 
neutral rates have declined to much lower levels compared to the pre-crisis period and show no sign of recovery (Laubach and Williams, 2015). Among other explanations proposed in the literature, demographic developments and the global savings glut are frequently used to explain this phenomenon. ${ }^{1}$ These low rates are challenging for policy-makers for two reasons. First, low neutral rates limit the scope of conventional monetary policy in stabilizing the economy. ${ }^{2}$ Second, low interest rates raise concerns about financial imbalances and risks to financial stability (Borio, 2016).

In this paper, we focus on the second issue, low interest rates change agents' behavior, in terms of the assets and liabilities they hold. ${ }^{3}$ Data show that accompanying the decline in the neutral interest rate, both household assets and liabilities have expanded, due to fast rising house prices. On the other hand, bank equity capital has also seen a substantial increase (See Figures A1-A2 in the Appendix). All these developments should have an effect on the implementation of the countercyclical buffer of Basel III financial regulations and therefore should be taken into account by macroprudential authorities. Higher borrowing has made financial markets more volatile, calling for stricter banking regulations for macroprudential purposes. However, higher capital makes banks safer, calling for a relaxation in the countercyclical buffer implementation of Basel requirements. As a result, there is the need to study these issues in a model that can account for those counteracting forces consistently and assesses the balance when implementing the Basel III countercyclical buffer.

This paper explores this issue in a DSGE model with housing and capital requirements for banks. First, we study how a low interest-rate environment affects the balance sheets of both consumers and banks. Then, we study how low interest rates affect financial and macroeconomic stability. Finally, we assess how to optimally implement the international regulation of Basel III in the context of low interest rates. ${ }^{4}$

The paper is related to several strands of the literature. It shares some features with papers that use DSGE models to assess the effects and optimality of capital requirement regulation (CRR) policy, especially in the context of Basel regulation. For instance, Angelini et al (2014) touches upon the relationship between monetary policy and capital requirements. In a similar fashion, Rubio and Carrasco-Gallego

\footnotetext{
${ }^{1}$ See: e.g., Bernanke (2005) and Bean et al. (2015).

${ }^{2}$ Rubio and Yao (2019) analyse this case and argue for the role of macroprudential policy when monetary policy is constrained by an occasionally binding lower bound.

${ }^{3}$ We abstract from the ZLB implications for monetary policy and we focus on the issue that the low interest-rate environment creates greater instability in financial markets.

${ }^{4}$ The model in its current form does not include unconventional monetary policy. One way to extend the model would be to include some sort of real money balances in the utility function, so that liquidity shocks could be included in case a zero lower bound was reached. However, this is out of the scope of the research question that is being considered here.
} 
(2016) find that monetary policy should be more aggressive when the countercyclical buffer of Basel III is applied. However, these papers do not take into account the low interest-rate environment. On the contrary, the papers that consider the decrease in the neutral interest rates tend to do it in the context of the zero lower bound (ZLB) for monetary policy but do not address the topic of financial regulation in isolation. For example, Antipa and Matheron (2014) study the interactions of macroprudential and unconventional monetary policies when the interest rate hits the ZLB. Lewis and Villa (2016) study the interactions between monetary policy and a countercyclical capital buffer when monetary policy is constrained at the ZLB. Korinek and Simsek (2016) find that when the interest rate is limited by the ZLB, welfare can be improved by ex-ante macroprudential policies such as debt limits and mandatory insurance requirements. Rubio and Yao (2019) study the interaction between LTV policy and monetary policy in a low interest-rate environment, in which the ZLB for the interest rate occasionally binds. We abstract from the interplay between monetary policy and the ZLB. To our knowledge, our paper is the first one that explores how the Basel regulation affects balance sheets of different agents in the low interest-rate economy, and further studies the optimal implementation of the Basel III regulation.

Results from the paper show that, consistently with empirical evidence, a low interest-rate environment increases bank capital because banks grant more mortgage lending to households. We also show that a low interest-rate environment leads the indebtedness of household to increase, leaving borrowers, as a whole, more exposed to credit risks when interest rates rise again. These results call for an active use of the countercyclical capital buffer of Basel III. An optimal policy analysis concludes that a rule on capital requirements, which proxies the countercyclical buffer in Basel III, needs to be more aggressive in a low interest-rate context to compensate for higher riskiness of borrowers.

The main weakness of our modeling choice is to calibrate the discount factor directly to model the decline in the nature rate of interest. In the literature, several papers discuss the long-run driving forces of decreasing nature rates, e.g. Hayashi and Prescott (2002) highlight the relationship between the evolution of real rates and the TFP growth in Japan. Eggertsson and Mehrotra (2014) argue for the role of the slow population growth and increased inequality in an OLG model. However, it is not straightforward to integrate those long-run driving forces into a business cycle representative-agent model. As a result, we adopt the parsimonious modeling approach to model the long-run change of real interest rate through the discount factor. This modelling choice has been used widely in the liquidity trap literature ( See: e.g. Krugman, 1998, Eggertsson and Woodford, 2003, Christiano, Eichenbaum and Rebelo, 2011 and Werning, 2012). Having said that, we do recognise that this tractable modelling 
choice might have non-trivial consequences for our results. For example, if the underlying driving forces are also affected by the CRR policy, our results might be biased. However, given that long-run driving forces, such as the population growth, the productivity growth, stressed in the literature are slow-moving and are unlikely affected by the change in financial policy, at least in the short run, we don't see our result should be fundamentally biased.

The rest of the paper continues as follows. Section 2 presents the modelling framework. Section 3 simulates the model. In Section 4, we discuss the effects of the low interest-rate environment on macroeconomic and financial stability. Section 5 relates the model to the international Basel regulation. Finally, in Section 6, we conclude.

\section{Model Setup}

The modelling framework is a DSGE model with a housing market and a banking sector, in the spirit of Iacoviello (2015). The economy features patient and impatient households, bankers, and a final goods firm. Households work and consume both consumption goods and housing. Patient and impatient households are savers and borrowers, respectively. Banks intermediate funds between savers and borrowers. Bankers are credit constrained in how much they can borrow from savers, and borrowers are credit constrained with respect to how much they can borrow from bankers. The representative firm converts household labor into the final good. The central bank follows a Taylor rule for the setting of interest rates. The countercyclical capital buffer of Basel III is represented by a Taylor-type rule for the setting of the capital requirement ratio.

\subsection{Savers}

Savers maximize their utility function by choosing consumption, housing and labor hours:

$$
\max E_{0} \sum_{t=0}^{\infty} \beta_{s}^{t}\left[\log C_{s, t}+j \log H_{s, t}-\frac{\left(N_{s, t}\right)^{\eta}}{\eta}\right],
$$

where $\beta_{s} \in(0,1)$ is the patient discount factor, $E_{0}$ is the expectation operator and $C_{s, t}, H_{s, t}$ and $N_{s, t}$ represent consumption at time $t$, the housing stock and working hours, respectively. $1 /(\eta-1)$ is the labor supply elasticity, $\eta>0 . j>0$ constitutes the relative weight of housing in the utility function. Subject to the budget constraint: 


$$
C_{s, t}+d_{t}+q_{t}\left(H_{s, t}-H_{s, t-1}\right)=\frac{R_{s, t-1} d_{t-1}}{\pi_{t}}+w_{s, t} N_{s, t}+\frac{X_{t}-1}{X_{t}} Y_{t}
$$

where $d_{t}$ denotes bank deposits, $R_{s, t}$ is the gross return from deposits, $q_{t}$ is the price of housing in units of consumption, and $w_{s, t}$ is the real wage rate. The last term refers to firms profits, which are rebated back to the saver, being $X_{t}$ the firm's markup and $Y_{t}$ the output. The first order conditions for this optimization problem are as follows:

$$
\begin{gathered}
\frac{1}{C_{s, t}}=\beta_{s} E_{t}\left(\frac{R_{s, t}}{\pi_{t+1} C_{s, t+1}}\right), \\
\frac{q_{t}}{C_{s, t}}=\frac{j}{H_{s, t}}+\beta_{s} E_{t}\left(\frac{q_{t+1}}{C_{s, t+1}}\right), \\
w_{s, t}=\left(N_{s, t}\right)^{\eta}-1 C_{s, t} .
\end{gathered}
$$

Equation (2) is the Euler equation, the intertemporal condition for consumption. Equation (3) represents the intertemporal condition for housing, which states that, at the margin, benefits for consuming housing equate costs in terms of consumption. Equation (4) is the labor-supply condition.

\subsection{Borrowers}

Borrowers solve:

$$
\max E_{0} \sum_{t=0}^{\infty} \beta_{b}^{t}\left[\log C_{b, t}+j \log H_{b, t}-\frac{\left(N_{b, t}\right)^{\eta}}{\eta}\right]
$$

where $\beta_{b} \in(0,1)$ is the impatient discount factor, subject to the budget constraint and the collateral constraint:

$$
\begin{gathered}
C_{b, t}+\frac{R_{b, t} b_{t-1}}{\pi_{t+1}}+q_{t}\left(H_{b, t}-H_{b, t-1}\right)=b_{t}+w_{b, t} N_{b, t}, \\
b_{t} \leq k E_{t}\left(\frac{1}{R_{b, t+1}} q_{t+1} H_{b, t} \pi_{t+1}\right)
\end{gathered}
$$

where $b_{t}$ denotes bank loans and $R_{b, t}$ is the gross interest rate. $k$ can be interpreted as a loan-to-value ratio (LTV). The borrowing constraint limits borrowing to the present discounted value of their housing 
holdings. The first order conditions are as follows:

$$
\begin{gathered}
\frac{1}{C_{b, t}}=\beta_{b} E_{t}\left(\frac{1}{\pi_{t+1} C_{b, t+1}} R_{b, t+1}\right)+\lambda_{b, t} \\
\frac{j}{H_{b, t}}=E_{t}\left(\frac{1}{C_{b, t}} q_{t}-\beta_{b} E_{t}\left(\frac{q_{t+1}}{C_{b, t+1}}\right)\right)-\lambda_{b, t} E_{t}\left(\frac{1}{R_{b, t+1}} k q_{t+1} \pi_{t+1}\right), \\
w_{b, t}=\left(N_{b, t}\right)^{\eta}-1 C_{b, t},
\end{gathered}
$$

where $\lambda_{b, t}$ denotes the multiplier on the borrowing constraint. ${ }^{5}$ These first order conditions can be interpreted analogously to the ones of savers.

\subsection{Financial Intermediaries}

Financial intermediaries solve the following problem:

$$
\max E_{0} \sum_{t=0}^{\infty} \beta_{f}^{t}\left[\log \operatorname{div}_{f, t}\right],
$$

where $\beta_{f} \in(0,1)$ is the financial intermediary's discount factor, subject to the budget constraint and the collateral constraint. $\operatorname{div}_{f, t}$ are dividends, which we assume are fully consumed by bankers every period, so that $\operatorname{div}_{f, t}=C_{f, t}$ :

$$
\operatorname{div}_{f, t}+\frac{R_{s, t-1} d_{t-1}}{\pi_{t}}+b_{t}=d_{t}+\frac{R_{b, t} b_{t-1}}{\pi_{t}}
$$

where the right-hand side measures the sources of funds for the financial intermediary; household deposits and repayments from borrowers on previous loans. These funds can be used to pay back depositors and to extend new loans, or can be used for their own consumption. As in Iacoviello (2015), we assume that the bank, by regulation, is constrained by the amount of assets minus liabilities. That is, there is a capital requirement ratio (We define capital as assets minus liabilities):

$$
\operatorname{Cap}_{t}=b_{t}-d_{t}
$$

Thus, the fraction of capital with respect to assets has to be larger than a certain ratio:

\footnotetext{
${ }^{5}$ Through simple algebra it can be shown that the Lagrange multiplier is positive in the steady state and thus the collateral constraint holds with equality.
} 


$$
\frac{b_{t}-d_{t}}{b_{t}} \geq C R R
$$

Simple algebra shows that this relationship can be rewritten as:

$$
d_{t} \leq(1-C R R) b_{t}
$$

If we define $\gamma=(1-C R R)$, we can reinterpret the capital requirement ratio condition as a standard collateral constraint, so that banks' liabilities cannot exceed a fraction of its assets, which can be used as collateral: ${ }^{6}$

$$
d_{t} \leq \gamma b_{t}
$$

where $\gamma<1$. The first order conditions for deposits and loans are as follows:

$$
\begin{gathered}
\frac{1}{\operatorname{div}_{f, t}}=\beta_{f} E_{t}\left(\frac{1}{\operatorname{div}_{f, t+1} \pi_{t+1}} R_{s, t}\right)+\lambda_{f, t}, \\
\frac{1}{\operatorname{div}_{f, t}}=\beta_{f} E_{t}\left(\frac{1}{\operatorname{div}_{f, t+1} \pi_{t+1}} R_{b, t+1}\right)+\gamma \lambda_{f, t},
\end{gathered}
$$

where $\lambda_{f, t}$ denotes the multiplier on the financial intermediary's borrowing constraint. ${ }^{7}$

\subsection{Final Goods Producers}

There is a continuum of identical final goods producers that operate under perfect competition and flexible prices. They aggregate intermediate goods according to the production function

$$
Y_{t}=\left[\int_{0}^{1} Y_{t}(z)^{\frac{\varepsilon-1}{\varepsilon}} d z\right]^{\frac{\varepsilon}{\varepsilon-1}},
$$

where $\varepsilon>1$ is the elasticity of substitution between intermediate goods. The final good firm chooses $Y_{t}(z)$ to minimize its costs, resulting in demand of intermediate good $z$ :

\footnotetext{
${ }^{6}$ Clerc et al. (2014) find, using a DSGE model, that the probability of default for banks is negligible for capital requirement ratios higher than $10 \%$. Basel III imposes a capital requirement ratio of $10.5 \%$, therefore, we assume that, taking into account the goal of the paper, in our model we do not have to include default risk for banks.

${ }^{7}$ Financial intermediaries have a discount factor $\beta_{f}<\beta_{s}$. This condition ensures that the collateral constraint of the intermediary holds with equality in the steady state, since $\lambda_{f}=\frac{\beta_{s}-\beta_{f}}{\beta_{s}}>0$
} 


$$
Y_{t}(z)=\left(\frac{P_{t}(z)}{P_{t}}\right)^{-\varepsilon} Y_{t}
$$

The price index is then given by:

$$
P_{t}=\left[\int_{0}^{1} P_{t}(z)^{1-\varepsilon} d z\right]^{\frac{1}{\varepsilon-1}}
$$

\subsection{Intermediate Goods Producers}

The intermediate goods market is monopolistically competitive. Following Iacoviello (2005), intermediate goods are produced according to the production function:

$$
Y_{t}(z)=A_{t} N_{s, t}(z)^{\alpha} N_{b, t}(z)^{(1-\alpha)}
$$

where $\alpha \in[0,1]$ measures the relative size of each group in terms of labor. ${ }^{8}$ This Cobb-Douglas production function implies that labor efforts of constrained and unconstrained consumers are not perfect substitutes. This specification is analytically tractable and allows for closed form solutions for the steady state of the model. This assumption can be economically justified by the fact that savers are the managers of the firms and their wage is higher than the one of the borrowers. ${ }^{9}$

$A_{t}$ represents technology and it follows the following autoregressive process:

$$
\log \left(A_{t}\right)=\rho_{A} \log \left(A_{t-1}\right)+u_{A t}
$$

where $\rho_{A}$ is the autoregressive coefficient and $u_{A t}$ is a normally distributed shock to technology. We normalize the steady-state value of technology to 1 .

Labor demand is determined by:

$$
\begin{gathered}
w_{s, t}=\frac{1}{X_{t}} \alpha \frac{Y_{t}}{N_{s, t}}, \\
w_{b, t}=\frac{1}{X_{t}}(1-\alpha) \frac{Y_{t}}{N_{b, t}},
\end{gathered}
$$

\footnotetext{
${ }^{8}$ Notice that the absolute size of each group is one.
}

${ }^{9}$ It could also be interpreted as the savers being older than the borrowers, therefore more experienced. 
where $X_{t}$ is the markup, or the inverse of marginal cost. ${ }^{10}$

The price-setting problem for the intermediate good producers is a standard Calvo-Yun setting. An intermediate good producer sells its good at price $P_{t}(z)$, and $1-\theta, \in[0,1]$, is the probability of being able to change the sale price in every period. The optimal reset price $P_{t}^{*}(z)$ solves:

$$
\sum_{k=0}^{\infty}(\theta \beta)^{k} E_{t}\left\{\Lambda_{t, k}\left[\frac{P_{t}^{*}(z)}{P_{t+k}}-\frac{\varepsilon /(\varepsilon-1)}{X_{t+k}}\right] Y_{t+k}^{*}(z)\right\}=0 .
$$

where $\varepsilon /(\varepsilon-1)$ is the steady-state markup.

The aggregate price level is then given by:

$$
P_{t}=\left[\theta P_{t-1}^{1-\varepsilon}+(1-\theta)\left(P_{t}^{*}\right)^{1-\varepsilon}\right]^{1 /(1-\varepsilon)} .
$$

Using (24) and (25), and log-linearizing, we can obtain a standard forward-looking New Keynesian Phillips curve $\widehat{\pi}_{t}=\beta E_{t} \widehat{\pi}_{t+1}-\psi \widehat{x}_{t}+u_{\pi t}$, that relates inflation positively to future inflation and negatively to the markup $(\psi \equiv(1-\theta)(1-\beta \theta) / \theta) . u_{\pi t}$ is a normally distributed cost-push shock. ${ }^{11}$

\subsection{Equilibrium}

The total supply of housing is fixed and it is normalized to unity, therefore house prices will be determined by demand. The market clearing conditions are as follows:

$$
\begin{gathered}
Y_{t}=C_{s, t}+C_{b, t}+C_{f, t}, \\
H_{s, t}+H_{b, t}=1 .
\end{gathered}
$$

Labor supply (equations 4 and 9) and labor demand (equations 22 and 23) are equal to each other, so that labor markets also clear. Equilibrium in financial markets is dictated by the regulatory constraint for banks, that is, $d_{t}=(1-C R R) b_{t}$.

\footnotetext{
${ }^{10}$ Symmetry across firms allows us to write the demands without the index $z$.

${ }^{11}$ Variables with a hat denote percent deviations from the steady state.
} 


\subsection{Monetary Policy and the Countercyclical Buffer}

In the standard new Keynesian model, the central bank aims at minimizing the variability of output and inflation. A subsidy could reduce the distortion introduced by nominal rigidities and monopolistic competition. However, in models with collateral constraints, the design of optimal policies involves a number of issues not considered in standard sticky-price models. In models with constrained individuals, there are three types of distortions: price rigidities, credit frictions and loan frictions. This creates conflicts and trade-offs between borrowers, savers, and banks. Savers may prefer policies that reduce the price-stickiness distortion. However, borrowers may prefer a scenario in which the pervasive effect of the collateral constraint is softened. Borrowers operate in a second-best situation. They consume according to the borrowing constraint as opposed to savers, who follow an Euler equation for consumption. Borrowers cannot smooth consumption by themselves, but a more stable financial system would provide them a setting in which their consumption pattern is smoother. In turn, banks may prefer policies that ease their capital constraint, since capital requirement ratios distort their ability to leverage and increase their dividends.

\subsubsection{Monetary Policy}

Monetary policy is set as follows:

$$
R_{s, t}=\left(R_{s, t-1}\right)^{\rho}\left(\left(\pi_{t}\right)^{\left(1+\phi_{\pi}^{R}\right)}\left(\frac{Y_{t}}{Y}\right)^{\phi_{y}^{R}} R\right)^{1-\rho}
$$

We consider a standard Taylor rule which responds to inflation and output, with interest-rate smoothing, where $\phi_{\pi}^{R} \geq 0, \phi_{y}^{R} \geq 0$ measure the response of interest rates to current inflation and output deviations from the steady state, ${ }^{12}$ respectively. $R$ is the steady-state interest rate.

\subsubsection{A rule for the Countercyclical Capital Buffer}

Here, following the Basel III guidelines, for the countercyclical buffer, we propose a Taylor-type rule that includes deviations of credit from its steady state, in order to explicitly promote stability and reduce systemic risk. This rule is analogous to the rule for monetary policy, but using the CRR as an instrument. It implies that the capital requirement ratio fluctuates around a steady state value, corresponding to the Basel III requirement for capital (10.5\%), and it increases when credit grows. The implementation of

\footnotetext{
${ }^{12}$ We use deviations of output with respect to the steady state as opposed to output gap because in a model with financial frictions there is no consensus about what the efficient level of output is.
} 
this rule would include the capital buffer stated in Basel III. Then, the optimal implementation of Basel III would be the value of the reaction parameter that maximizes welfare:

$$
C R R_{t}=C R R_{S S}\left(\frac{b_{t}}{b_{t-1}}\right)^{\phi_{b}^{\gamma}}
$$

This rule states that, whenever regulators observe that credit grows, they automatically increase the capital requirement ratio to avoid an excess in credit.

\subsection{Parameter Values}

For simulations, we create two types of environments. In the "high interest-rate" environment, the steady-state annual interest rate is $4 \%$ as in the standard RBC models (See: e.g. Kydland and Prescott, 1982). In this case, the discount factor for savers, $\beta_{s}$, is set to 0.99 so that the annual interest rate is $4 \%$ in steady state. The discount factor for borrowers is set to $0.98 .{ }^{13}$ We also set the discount factors for bankers at 0.965 , which implies a spread of about 1 percent (on an annualized basis) between lending and deposit rates for the leverage parameter of $10 \%$. In the "low interest-rate" environment, we choose the steady-state interest rate to be $2 \%$, which roughly amounts to the average estimate of natural interest rates between 1995 to 2007 by Laubach and Williams (2015). This leads us to set $\beta_{s}$ to 0.995 . In order to keep the same difference across agents' discount factors in both scenarios, we set $\beta_{b}$ to 0.985 and $\beta_{f}$ to 0.97 , accordingly.

The steady-state weight of housing in the utility function, $j$, is set to 0.1 in order for the ratio of housing wealth to GDP to be approximately 1.40 in the steady state, consistent with the US data. Increasing the weight of housing in the utility function would in turn make this variable more sensitive to shocks. We calibrate it in line with Iacoviello (2005) and Iacoviello and Neri (2010). Unless it is unrealistically increased, differences in simulations are negligible. We set $\eta=2$, implying a value of the labor supply elasticity of 1 . The value that we use makes it closer to realistic values widely used in macro models with collateral constraints, such as the ones estimated by Iacoviello and Neri (2010). In fact, microeconomic estimates usually suggest values in the range of 0 and 0.5 (for males). Domeij and Flodén (2006) show that, in the presence of borrowing constraints, these estimates could have a downward bias of $50 \%$.

For the parameters controlling leverage, we set $k$ in line with the US data (Iacoviello, 2015). $\gamma$ is the

\footnotetext{
${ }^{13}$ Lawrance (1991) estimated discount factors for poor consumers at between 0.95 and 0.98 at quarterly frequency. We take the most conservative value.
} 
parameter governing the CRR, which we set according to the Basel regulations (CRR of $8 \%$ for Basel I,II and 10.5\% for Basel III). The labor-income share for savers is set to 0.64, following Iacoviello (2005).

We assume that technology, $A_{t}$, follows an autoregressive process with 0.9 persistence and a normally distributed shock. ${ }^{14}$ Table 1 presents a summary of the parameter values used.

\begin{tabular}{|c|c|c|}
\hline \multicolumn{3}{|c|}{ Table 1: Parameter Values } \\
\hline \hline$\beta_{s}$ & $.99 / .995$ & Discount Factor for Savers \\
\hline$\beta_{b}$ & $.98 / .985$ & Discount Factor for Borrowers \\
\hline$\beta_{f}$ & $.965 / .97$ & Discount Factor for Banks \\
\hline$j$ & .1 & Weight of Housing in Utility Function \\
\hline$\eta$ & 2 & Parameter associated with labor elasticity \\
\hline$k$ & .90 & Loan-to-value ratio \\
\hline$\alpha$ & .64 & Labor income share for Savers \\
\hline$\theta$ & .75 & Calvo Probability \\
\hline$\rho_{A}$ & .9 & Technology persistence \\
\hline BI,II $C R R$ & .08 & CRR for Basel I, II \\
\hline BIII $C R R$ & .105 & CRR for Basel III \\
\hline
\end{tabular}

\section{Analysis}

\subsection{Balance Sheets in US Data}

For a better understanding of the structure of the model, we illustrate assets and liabilities of different agents in Table 2:

\begin{tabular}{|c|c|c|c|c|c|c|}
\hline \multicolumn{7}{|c|}{ Table 2: Assets and Liabilities } \\
\hline \hline & \multicolumn{2}{|c|}{ Savers } & \multicolumn{2}{c|}{ Borrowers } & \multicolumn{2}{c|}{ Banks } \\
\hline \hline & Assets & Liabilities & Assets & Liabilities & Assets & Liabilities \\
\hline Housing & $q_{t} H_{s, t}$ & & $q_{t} H_{b, t}$ & & $b_{t}$ & $d_{t}$ \\
\hline Deposits/Debt & $d_{t}$ & & & $b_{t}$ & & \\
\hline Equity Capital & & & & & & Cap $_{t}$ \\
\hline Leverage & \multicolumn{2}{|c|}{0} & \multicolumn{2}{c|}{$b_{t} / q_{t} H_{b, t}$} & \multicolumn{2}{c|}{ Cap $_{t} / b_{t}$} \\
\hline
\end{tabular}

\footnotetext{
${ }^{14}$ The persistence of the shocks is consistent with the estimates in Iacoviello and Neri (2010).
} 
Savers' assets consist of both housing wealth $\left(q_{t} H_{s, t}\right)$ and deposits $\left(d_{t}\right)$, while borrowers have housing wealth $\left(q_{t} H_{b, t}\right)$ on the asset side, but debt $\left(b_{t}\right)$ on the liability side. The current leverage ratio of borrowers is defined as $b_{t} / q_{t} H_{b, t}$. Banks' balance sheet mirrors those from households with loans as assets and deposits as liabilities. The difference between banks' assets and liabilities is the banks' equity capital $\left(\mathrm{Cap}_{t}\right)$, which is affected by the capital requirement ratio.

As we show in Figure (A1-A2) in the Appendix, all compositions of balance sheets have changed substantially in the US since 1980s, although this can be applicable to other countries. As shown in the left panel of Figure A1, the main components of both assets and liabilities are related to housing. ${ }^{15}$ On the asset side, currency holding and deposits are relatively stable over time. So is the non-housing part of nonfinancial assets (the blue region above the red line). ${ }^{16}$ The major component that has fluctuated significantly is housing assets, which rose substantially before the GFC and then fell sharply. On the liability side, mortgage loans followed a similar pattern as housing assets, while consumer loans and other liabilities are relatively stable. In the right panel, we construct a measure of household leverage according to our model setup, i.e. the ratio between the sum of mortgage loans and consumer loans and housing assets. We see that household leverage rose substantially in the 1990s and then fell shortly because of the strong growth in house prices. In the wake of the GFC, household leverage rose sharply because of the housing market crash between 2008 and 2010.

In the left panel of Figure A2, we depict total assets of the US commercial banks and its main components. ${ }^{17}$ On the one hand, banks' assets increased substantially since the middle of 1990s. Before the GFC, housing loans contributed the most to this development. On the other hand, the bank equity capital has also been rising significantly since the early 2000s. In the right panel, we have plotted the ratio between bank equity capital and total assets. The capital ratio increased from about $7 \%$ in the early 1980 s to around $11 \%$ in the post GFC periods.

\footnotetext{
${ }^{15}$ Data source: Federal Reserve Economic Data, Federal Reserve Bank of St. Louis. We use the following series to construct the chart: "TABSHNO" for Total Assets; "TFAABSHNO" for Total Financial Assets; "HNOREMQ027S" for Real Estate; "HNONASQ027S" for nonfinancial assets; "DABSHNO" for Total Currency and Deposits Including Money Market Fund Shares; "HNOTSDQ027S" for total time and savings deposits; "TLBSHNO" for Total Liabilities; "HHMSDODNS" for Home Mortgages; "HCCSDODNS" for Consumer Credit.

${ }^{16}$ Nonfinancial assets include: real estate, equipment, nonresidential intellectual property products, and consumer durable goods.

${ }^{17}$ Data source: H.8 Assets and Liabilities of Commercial Banks in the United States, Board of Governors of the Federal Reserve System.
} 


\subsection{Data vs. Model}

In Table 3, we report key statistics from data and compare them with model's numerical results. First, we contrast our model with data between 1984 and 2007, period in which the Taylor rule was arguably a good approximation of the US monetary policy. We then split the whole sample into two subsets around 1997, corresponding to the high and the low interest-rate environment, respectively. In the first row, we show the sample average of the real interest rate, measured by the federal funds rate minus the GDP deflator. We see that the first subsample has a much higher average real interest rate $(4.7 \%)$ than the second subsample $(1.9 \%)$, which we call the low interest-rate environment. These magnitudes are comparable with the calibration values for the steady-state interest rates in the model. The second row reports the average capital ratio of the US commercial banking sector. The first subsample has an average capital ratio of $7.5 \%$, while it is $9.6 \%$ in the second period. These numbers are also broadly consistent with our calibration, according to Basel II and III regulations.

\begin{tabular}{|l|c|c|c|c|c|c|}
\hline \multicolumn{7}{|c|}{ Table 3: Model vs. Data } \\
\hline \hline & \multicolumn{3}{|c|}{ Data } & \multicolumn{3}{c|}{ Model } \\
\hline \hline & High $i$ & Low $i$ & $\Delta \%$ & High $i$ & Low $i$ & $\Delta \%$ \\
\hline Real rate* & $4.7 \%$ & $1.9 \%$ & $-60 \%$ & $4 \%$ & $2 \%$ & $-50 \%$ \\
\hline Capital ratio & $7.5 \%$ & $9.6 \%$ & $28 \%$ & $8 \%$ & $10.5 \%$ & $31 \%$ \\
\hline Housing assets/GDP & 1.2 & 1.5 & $22 \%$ & 2.2 & 3.3 & $50 \%$ \\
\hline Debt (Borrowing)/GDP & 0.5 & 0.7 & $42 \%$ & 1.9 & 2.9 & $53 \%$ \\
\hline Deposit (Savers)/GDP & 0.5 & 0.42 & $-17 \%$ & 1.8 & 2.6 & $44 \%$ \\
\hline LTV & $44 \%$ & $51 \%$ & $16 \%$ & 0.9 & 0.9 & 0 \\
\hline
\end{tabular}

Next, we contrast the key endogenous variables from the model with their counterparts in the data. One of the key features of our model is to integrate housing and the collateral constraint into an otherwise standard household problem. Housing plays a key role for households, not only because it generates utility, but also because it serves as collateral for loans. As a result, in the model, housing wealth is the key driver of the household balance sheet, especially for borrowers. Our data confirm this view taken in the model's construction. The housing assets to GDP ratio rose by $22 \%$ between the two subsamples, and the debt-to-GDP ratio increased even more substantially by $42 \%$. These key developments in the US economy are captured by our model with a lower steady-state interest rate. In the right panel, we show that dropping the steady state interest rate from $4 \%$ to $2 \%$ leads the housing-to-GDP ratio to 
increase from 2.2 to 3.3 , by $50 \%$, and the debt-to-GDP ratio to rise by $53 \%$. The model overstates the increase in those ratios somewhat, but it is broadly consistent with the data. What it is not captured by the model is the deposit-to-GDP ratio, which is declined in the data, but increases substantially in the model. This is because our model is a closed-economy model, in which all additional lending has to be financed either by an increase in deposits or in bank capital. Given that we calibrate the increase in bank capital according to Basel regulations, the large increase in lending can only be met by deposits. In the real world, however, the US borrows in large scale from the rest of the world, especially from eastern Asian countries. This fact has been widely regarded as the key factor that contributed to both the rise in household borrowing and the decline in interest rates in the US ( See Bernanke,2005, among others).

For completeness, we also report the loan-to-value ratio (LTV). In the US data, we construct it by adding mortgage loans and consumer loans and dividing it by housing assets. The average value rose by 16\%. This is consistent with the debt-to-GDP ratio, showing that the economy is more leveraged in the low interest-rate environment. Our model, however, cannot generate the increase in the LTV, simply because it is fixed at 0.9 for both the high and the low interest-rate environment. In our model, the elevated household leverage is captured by the debt-to-GDP ratio, instead of the LTV.

In sum, we show in this section that our model captures the key developments in the low interest-rate economy. In particular, low interest rates lead to housing wealth being a more important component of the household balance sheet and borrowers in the economy being more leveraged. This fact makes the call for using macroprudential policies, including countercyclical buffers and increases in the CRR, stronger in the low interest-rate environment. In the next section, we use our model to analyze the effect of policy instruments with capital requirements in the dynamics of the economy.

\section{Macroprudential Policy with Capital Requirements}

In this section, we move our focus to the dynamics of the economy. We use our model with a low steady-state interest rate to study how different macroprudential policy with capital requirements affects macroeconomic and financial stability, which are measured by the volatility of real and financial variables, respectively. In particular, we first focus on increasing the CRR and then, we study the optimal implementation of the countercyclical capital buffer, as in the international Basel III regulation. 

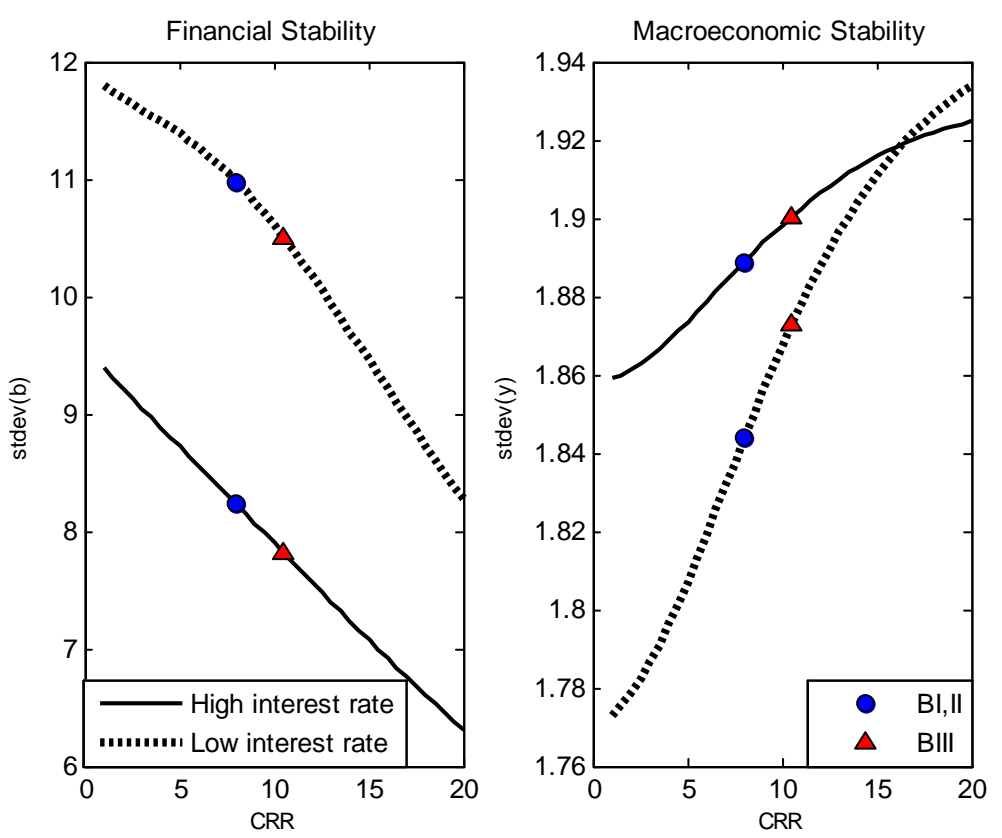

Figure 1: Financial and Macroeconomic Stability. High and Low interest rate

\subsection{Increase in the CRR}

In the previous section, we learnt that the decrease in the interest rate, on the one hand, has increased the amount of assets held by agents but on the other hand, has also increased indebtedness of borrowers. These changes make the economy more sensitive to financial conditions, calling for the use of macroprudential policy. As shown in Figure ??, we depict the financial and macroeconomic stability over different levels of the CRR. Financial and macroeconomic stabilities are measured by the standard deviation of credit and output, respectively. We show results for both high and low interest-rate environments.

We see that, unambiguously, for all levels of capital requirements, there is a clear trade-off between financial and macroeconomic stability. With a tighter CRR, credit becomes less volatile, but output is variable. In addition, comparing high and low interest-rate environments, it becomes clear that financial instability is more of a concern in a low interest-rate economy, and thus the call for a tighter CRR is more warranted. However, it comes at a bigger cost in terms of macroeconomic stability. When the macroprudential authority makes banks safer, the side-effect of this policy is to limit their lending capacity, and this in turn will make borrowers harder to smooth their consumption. This intuition is confirmed by the impulse response functions, illustrated in Figure 2. Higher CRR makes the economy less leveraged, as it is captured by the credit-to-GDP ratio. However, in this economy, borrowers cannot get credit to smooth their consumption. As a result, borrowers' consumption rises sharply on impact, 

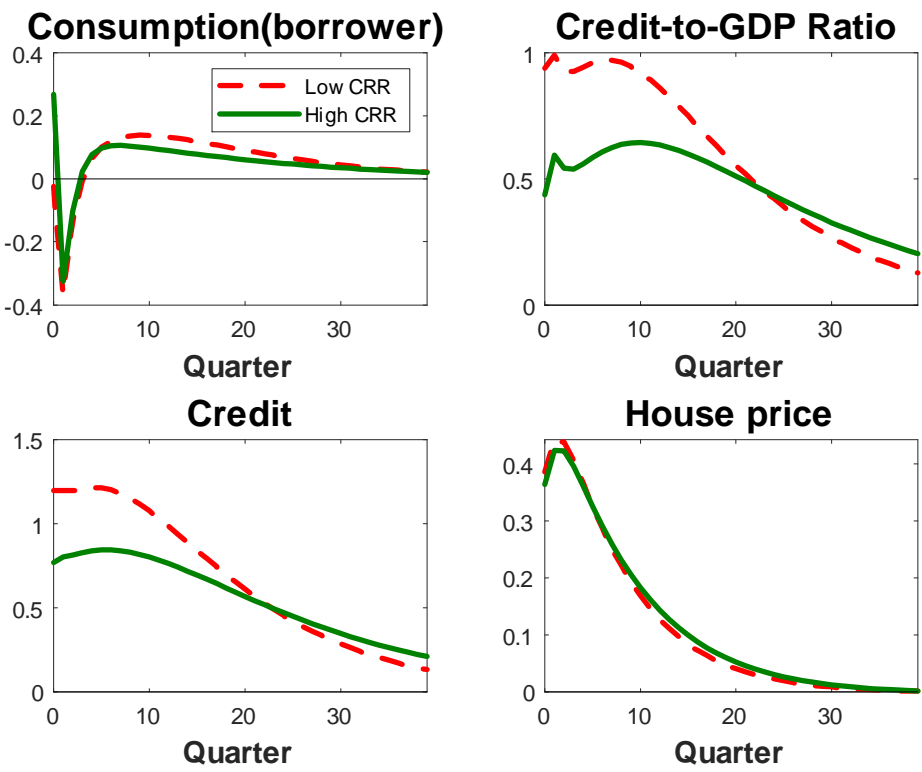

Figure 2: Impulse Responses to a positive technology shock in a low interest-rate economy

following a positive technology shock. Analogously, if the CRR is lower, borrowers use more credit to substitute their consumption intertemporally and, as a result, the economy becomes less volatile.

It is also important to observe that, in the low interest-rate environment, the trade-off between financial stability and macroeconomic stability becomes worse. This manifests in the right panel of Figure ??; the curve associated with a high interest rate is steeper than the curve in the low interest-rate economy. This means that to achieve a given level of reduction in financial stability with a higher CRR, the economy will suffer from more macro instability.

In light of these results, it seems that even though banks are safer when the CRR is set high, borrowers become more vulnerable in the face of shocks. This trade-off becomes worse when the interest rate becomes lower. Given this consideration, the low interest-rate environment calls for a macroprudential use of Basel III regulation and an optimal implementation of the countercyclical capital buffer. Next section discusses this issue.

\subsection{The Countercyclical Capital Buffer}

In this section, we calculate the optimal parameters in equation 29 , in the sense that they maximize consumer welfare. We define the following measure of welfare, for savers and borrowers:

$$
W_{s, t} \equiv E_{t} \sum_{m=0}^{\infty} \beta_{s}^{m}\left[\log C_{s, t+m}+j \log H_{s, t+m}-\frac{\left(N_{s, t+m}\right)^{\eta}}{\eta}\right]
$$




$$
W_{b, t} \equiv E_{t} \sum_{m=0}^{\infty} \beta_{b}^{m}\left[\log C_{b, t+m}+j \log H_{b, t+m}-\frac{\left(N_{b, t+m}\right)^{\eta}}{\eta}\right],
$$

Following Mendicino and Pescatori (2007), we aggregate welfare as a weighted sum of the individual welfare for the different types of households. Each agent's welfare is weighted by her discount factor, respectively, so that the all the groups receive the same level of utility from a constant consumption stream. Then, we can define households' welfare as:

$$
W_{h, t}=\left(1-\beta_{s}\right) W_{s, t}+\left(1-\beta_{b}\right) W_{b, t},
$$

Table 4 and Figure $(3-4)$ compare results of the optimal simple rule exercise in both high and low interest-rate environment. Each row contains the optimal value of $\phi_{b}^{\gamma *}$ that maximizes the social welfare and variances of output and credit resulted from the optimal value of the policy coefficient. For comparison, we first report results in the high interest-rate environment (4\% steady-state interest rate), while in the second row, results are generated for the low interest-rate scenario $(2 \%$ steady-state interest rate). Note that both economies are driven by the productivity shock and we discuss the robustness of our key results for other types of shocks in a later section.

\begin{tabular}{lccc}
\hline \hline Table 4: Optimal CCR policy & \\
\hline \hline Technology shocks & $\phi_{b}^{\gamma *}$ & $\sigma_{b}$ & $\sigma_{y}$ \\
\hline High interest rate & 0.0 & $6.1 \%$ & $3.9 \%$ \\
Low Interest Rate & 4.6 & $22.7 \%$ & $2.7 \%$ \\
\hline \hline
\end{tabular}

First of all, driven by the productivity shocks, the economy in the high interest-rate environment is significantly less volatile than that in the low interest-rate environment. As a result, countercyclical capital buffer is not needed in the high interest-rate world. By contrast, in the low interest-rate environment, the same shock process genearates much more volatility in credit. This leads to a significant increase in the welfare loss for credit-constrained borrowers. Consequently, the optimal implementation of the CCR policy responds stronger to the credit growth. As illustrated in Figure $(3-4)$, the active CCR policy has important welfare consequences for the agents in the economy. By decomposing the social welfare into those from the savers versus borrowers, we reveal that there is a trade-off between the welfare of savers and borrowers. Actively responding to the credit growth by the macroprudential policy redistributes welfare from savers to borrowers. This is especially true in the low interest-rate 

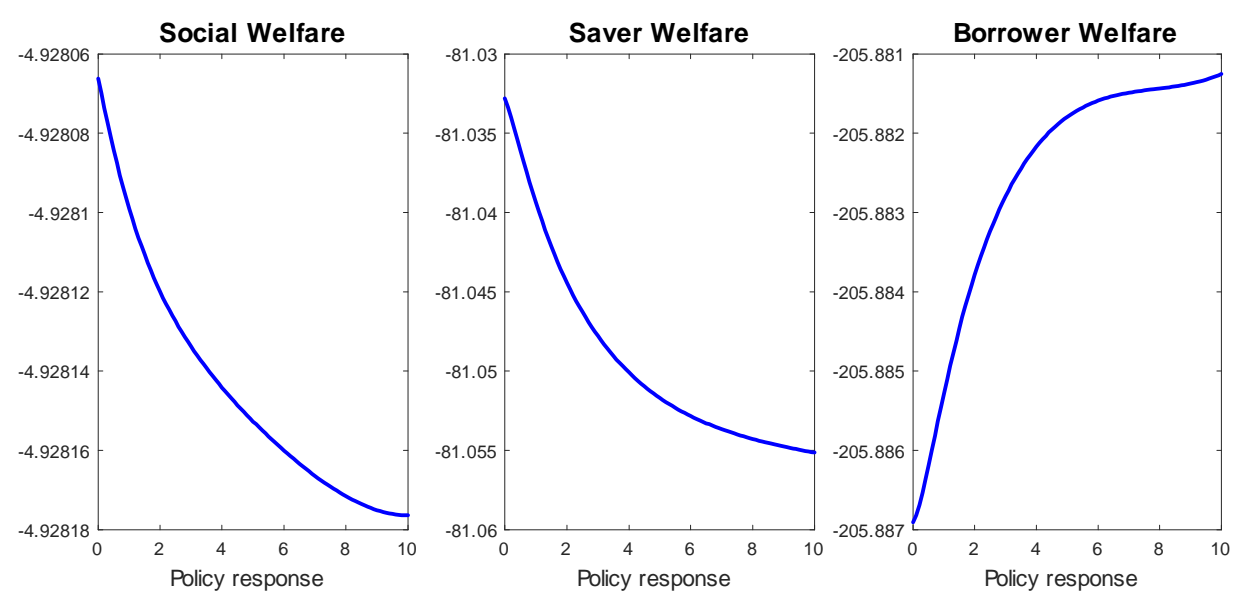

Figure 3: Optimal CRR response in the high interest rate environment
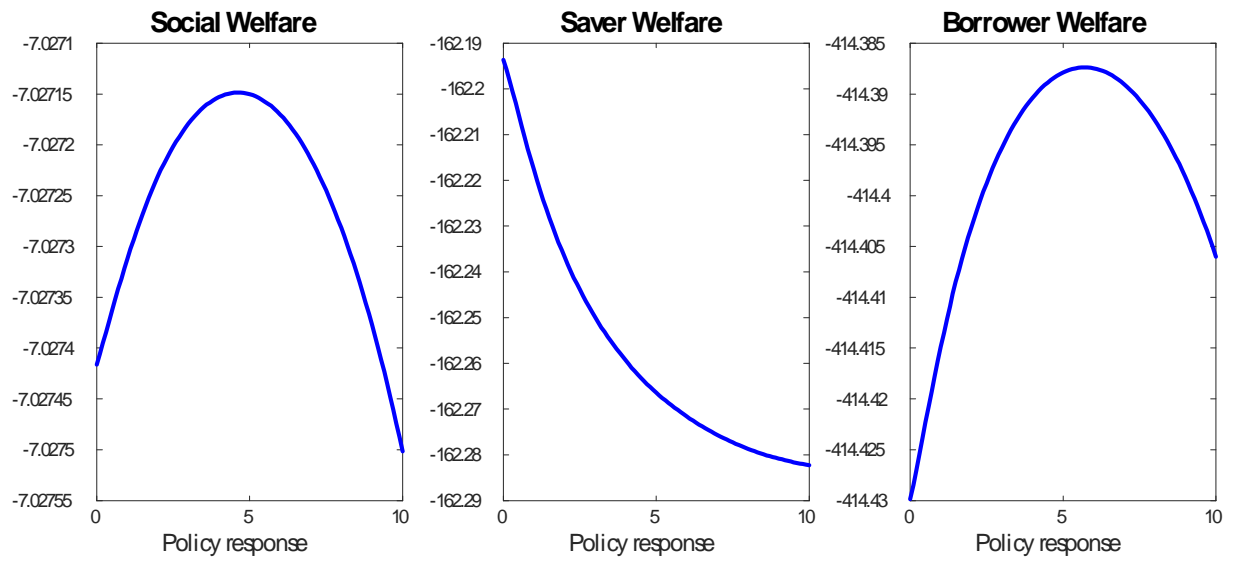

Figure 4: Optimal CRR response in the low interest rate environment

environment.

The economic reason is as follows: savers can smooth their consumption by using their savings freely, but borrowers are credit constrainted by the collateral value that they possess. As a result, savers's welfare is mainly driven by the macroeconomic fluctuations, such as the volatility in inflation and the output growth, while borrowers' welfare is primarily affected by the fluctuations of financial variables, such as house prices and credit. In other words, the welfare of different agents in the economy is linked to the volatility of different variables in the economy. As we discussed in Figure (1), a permanent shift in the CCR policy introduces a trade-off between financial and macroeconomic stability. This is also true in the time-varying case. A tighter CRR gives rise to a less volatile financial environment, but more variable macroeconomic fluctuations. The welfare of savers generally decreases with the strength of the 
policy response coefficient, while the borrowers' welfare is improved with enhanced financial stability. In the low interest-rate environment, since challenges for financial stability are stronger, the rule needs to be more aggressive, in the sense that the optimal parameter for the credit response is larger.

\subsection{Robustness}

\subsubsection{Alternative shocks}

In the DSGE literature, researchers estimate medium-scale DSGE models using the Bayesian estimation (See: e.g. Smets and Wouters, 2007 and Iacoviello and Neri, 2010 among many others). They show that the model needs a wide range of shocks, such as different types of productivity shocks, preference shocks, cost-push/markup shocks, and monetary policy shocks, to account for the dynamics of the US time series data. Compared to their medium-scale DSGE model, our model is still very stylised and designed to illustrate the mechanism, instead of fitting to data. To check the robustness of our theoretical results, we adopt a compromised strategy to select some stylised shocks and calibrate them with the empirical estimates from the Bayesian DSGE literature.

Table 5: Welfare analysis under other shocks

\begin{tabular}{l|ccc|cccc|ccc|ccc}
\hline \hline & \multicolumn{3}{|c|}{ Demand shock } & \multicolumn{3}{c|}{ Monetary shock } & \multicolumn{2}{c|}{ Cost-push shock } & \multicolumn{3}{c}{ All shocks } \\
\hline & $\phi_{b}^{\gamma *}$ & $\sigma_{b}$ & $\sigma_{y}$ & $\phi_{b}^{\gamma *}$ & $\sigma_{b}$ & $\sigma_{y}$ & $\phi_{b}^{\gamma *}$ & $\sigma_{b}$ & $\sigma_{y}$ & $\phi_{b}^{\gamma *}$ & $\sigma_{b}$ & $\sigma_{y}$ \\
High interest rate & 0.0 & 6.29 & 3.96 & 1.7 & 17.53 & 5.28 & 0.0 & 6.33 & 3.97 & 1.7 & 17.75 & 5.31 \\
Low Interest Rate & 4.9 & 23.27 & 2.76 & 5.5 & 53.00 & 6.57 & 4.7 & 23.23 & 2.80 & 5.6 & 53.65 & 6.62 \\
\hline \hline
\end{tabular}

In the baseline case, we show the welfare results conditional on productivity shocks. In this section, we add more shocks to the model and show the robustness of our main finding in the last section. The first shock that we are adding on is a consumption preference shock. As in Smets and Wouters (2007), this is a shock that directly hits the consumption utility function and affects the intertemporal substitution of households. The estimated persistence of the consumption preference shock is 0.18 with the standard deviation of $0.24 \%$. The welfare results are shown in the first three columns in Table 5 . There is no material change in terms of optimal value of the CRR policy coefficient in both high and low interest-rate environment. We then add an i.i.d. shock to the monetary policy rule. The shock has a standard deviation of $0.24 \%$. Adding a nominal shock is important, as it substantially enhances the volatility of both real and financial variables. As a result, the active CRR policy responds more strongly both in high and low interest-rate world. Again, our main conclusion is the same for the monetary 
policy shock. Next, we also consider a second type of supply shocks, which affect inflation directly. In particular, we add a cost-push shock into the New Keynesian Phillips curve. We use the estimates of Smets and Wouters (2007) for the US economy as an empirically plausible size of the shock. We assume that the cost-push shock has the persistence of 0.89 and a standard deviation of $0.14 \%$. The welfare results are very similar to those from the productivity shock. Both supply shocks affect the economy in a similar way and therefore has the similar implication for the implication of the CCR policy. Last, we document the final welfare results under all shocks. This set of results look similar to those from the monetary policy shock, because it contributes the most to the volatility of credit in the economy. As a result, the optimal CRR policy responds strongly to the credit growth, compared to other shocks individually, and this is more true in the low interest environment.

\subsubsection{Alternative CRR rules}

In this subsection, we consider a wider range of CRR rules, which respond to other financial imbalance indicators. In the benchmark model, we use the credit growth as the indicator for financial instability in the CRR rules. Alternatively, it is equally justifiable to use the credit gap and the credit-to-GDP ratio as the indicator of financial instability. ${ }^{18}$ The result is summarised in Table 6 . In both cases, our main finding is robust to the alternative policy rules used.

\begin{tabular}{|c|c|c|}
\hline & $C C R R_{t}=\left(C R R_{S S}\right)\left(\frac{b_{t}}{b_{s s}}\right)^{\phi_{b}^{\gamma}}$ & $C R R_{t}=\left(C R R_{S S}\right)\left(\frac{b_{t}}{Y_{t}}\right)^{\phi_{b}^{\gamma}}$ \\
\hline High interest rate & 2.9 & 2.4 \\
\hline Low Interest Rate & 5.3 & 6.8 \\
\hline
\end{tabular}

\section{Conclusions}

In this paper, we use a DSGE model with housing and a banking sector to study the effects of the decrease in the natural rate of interest, which is observed in the data. In particular, we study how the decrease in the neutral rates has affected the balance sheets of both households and banks at the steady state. We also investigate how low interest rates affect economic dynamics, which are related to the policy discussion about macroeconomic and financial stability. In light of these results, we propose an optimal way to implement the international Basel III regulation, in this new low interest-rate context.

\footnotetext{
${ }^{18}$ Those variables are shown in empirical studies (see, e.g.: Drehmann and Juselius, 2014) as a good early warning indicator of banking crises.
} 
We show that our model captures some key developments of the household balance sheet, as observed in the data since the early 1980s. On the one hand, a decrease in the interest rate increases the value of housing assets and makes it one of the largest components of the households' balance sheet. On the other hand, borrowers in the economy become more indebted, calling for a more active use of macroprudential policy with capital requirements regulations. We then show that an increase in CRR helps stabilizing financial cycles, but it also brings a side-effect on macro stability. Finally, we study the optimal implication of the Basel III regulation within the model. We find that for the low interest-rate environment, since there are more challenges to financial stability, the rule that proxies the countercyclical buffer in Basel III needs to be more aggressive on credit cycles. 


\section{Appendix}

\section{Tables and Figures}
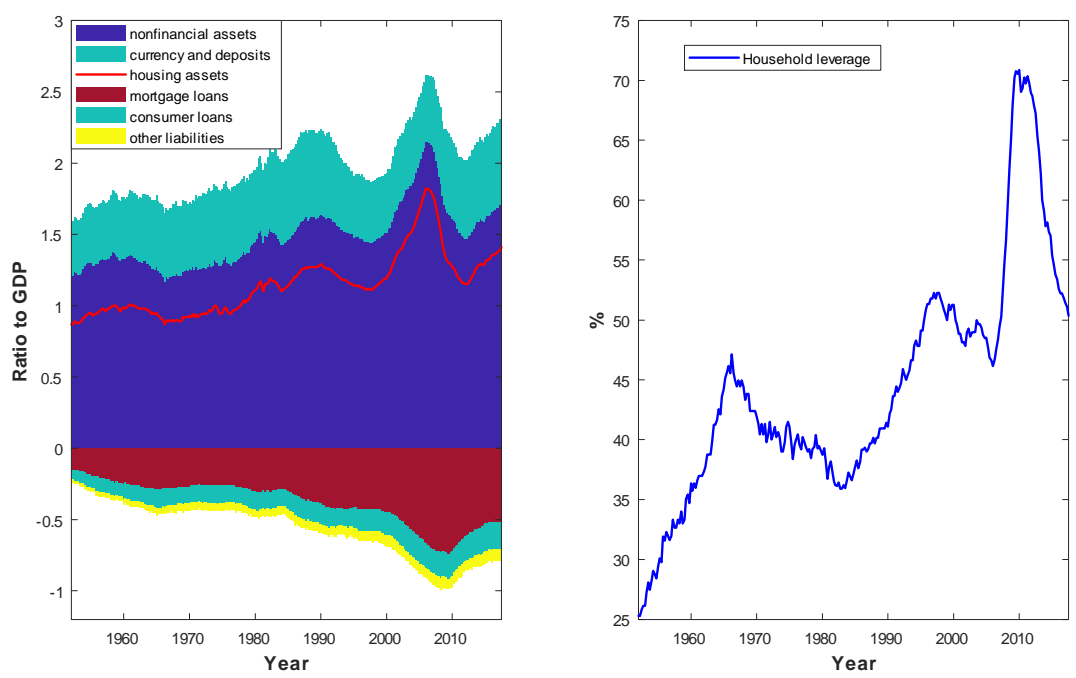

Figure A1: U.S. Household Balance Sheet and Leverage, 1980 - 2017
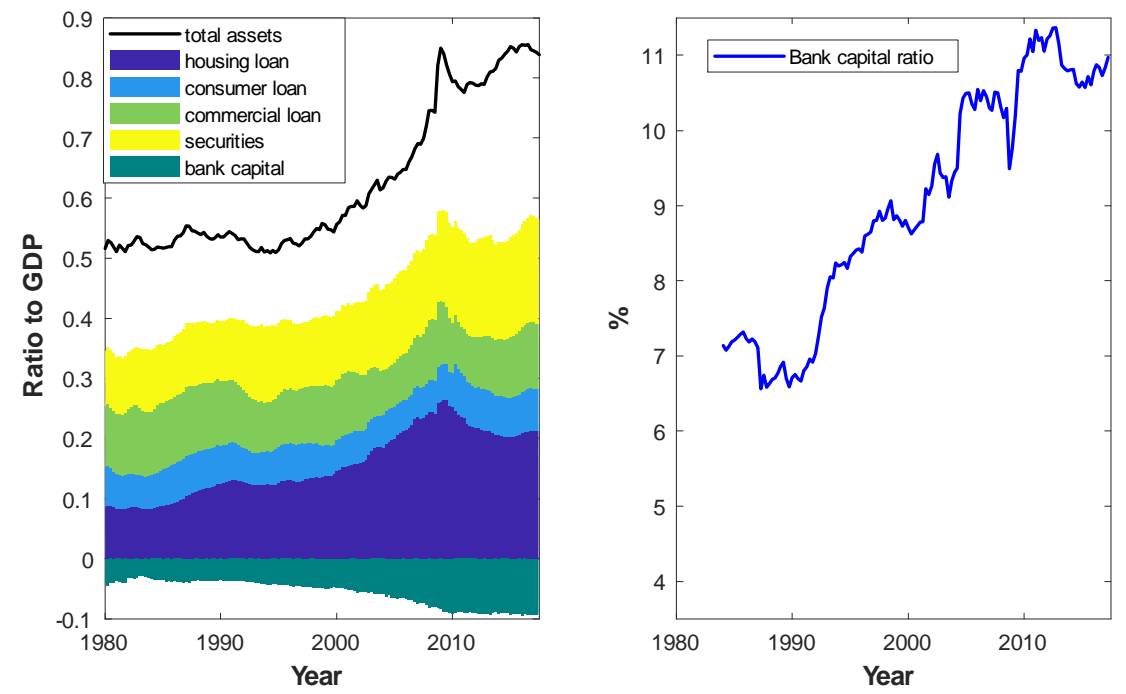

Figure A2: U.S. Commercial Banks' Balance Sheet and the Leverage Ratio, 1980 - 2017 


\section{Steady State}

Using equation (2) in the steady state, we obtain:

$$
R_{s}=\frac{1}{\beta_{s}}
$$

Equation (3) in the steady state delivers the housing to consumption ratio for savers in the steady state:

$$
\frac{q H_{s}}{C_{s}}=\frac{j}{\left(1-\beta_{s}\right)}
$$

Combining equations (15) and (16) in the steady state, we obtain:

$$
R_{b}=\frac{\widetilde{\beta}}{\beta_{s} \beta_{f}}
$$

where $\widetilde{\beta}=\gamma \beta_{f}+(1-\gamma) \beta_{s}$.

And

$$
\lambda_{f}=\frac{1}{C_{f}}\left(\frac{\beta_{s}-\beta_{f}}{\beta_{f}}\right),
$$

which implies that equation (14) holds with equality in the steady state as long as $\beta_{s}>\beta_{f}$.

Combining equation (7) in the steady state with $(A 3)$, we obtain:

$$
\lambda_{b}=\frac{1}{C_{b}}\left(1-\frac{\beta_{b} \widetilde{\beta}}{\beta_{s} \beta_{f}}\right),
$$

which implies that the collateral constraint for borrowers, equation (6), holds with equality in the steady state as long as $\beta_{b} \widetilde{\beta}<\beta_{s} \beta_{f}$.

Equation (8) in the steady state, combined with equations $(A 5)$ and $(A 3)$ deliver:

$$
\frac{q H_{b}}{C_{b}}=\frac{j}{1-\beta_{b}-k\left(\frac{\beta_{s} \beta_{f}}{\widetilde{\beta}}-\beta_{b}\right)} .
$$

Equation (14) in the steady state:

$$
d=\gamma b
$$


which implies

$$
C a p=(1-\gamma) b
$$

Combining $(A 8)$ with $(6)$ in the steady state and $(A 3)$, we obtain:

$$
\frac{C a p}{C_{b}}=\frac{(1-\gamma) k j}{\frac{\widetilde{\beta}}{\beta_{s} \beta_{f}}-k-(1-k) \frac{\widetilde{\beta} \beta_{b}}{\beta_{s} \beta_{f}}} .
$$




\section{References}

[1] Aikman, D, A Haldane, M Hinterschweiger and S Kapadia (2018): "Rethinking Financial Stability", Bank of England Working Paper 712

[2] Angelini, P., Neri, S., Panetta, F., (2014), "The Interaction between Capital Requirements and Monetary Policy." Journal of Money, Credit and Banking, Volume 46, Issue 6, pp. 1073-1112

[3] Antipa, P. \& Matheron, J., (2014), "Interactions between monetary and macroprudential policies," Financial Stability Review, Banque de France, issue 18, pages 225-240

[4] Barth, J R and S M Miller (2018): "Benefits and costs of a higher bank leverage ratio", Journal of Financial Stability, vol 38, pp 37-52

[5] Basel Committee on Banking Supervision, (2019), "The costs and benefits of bank capital - a review of the literature," Working Paper 37

[6] Bean, C., Broda, C., Ito, T., and Kroszner, R., (2015), Low for Long? Causes and Consequences of Persistently Low Interest Rates Geneva Reports on the World Economy 17

[7] Bernanke, B., (2005), The global saving glut and the U.S. current account deficit, Speech 77, Board of Governors of the Federal Reserve System

[8] Borio, C., (2016), Towards a financial stability-oriented monetary policy framework?, BIS speech, SP160914

[9] Christiano, L., Eichenbaum, M., Rebelo, S., (2011). "When Is the Government Spending Multiplier Large?," Journal of Political Economy, University of Chicago Press, 119 (1), pp. 78-121

[10] Dagher, J, G Dell'Arriccia, L Laeven, L Ratnovski and H Tong (2016): "Benefits and costs of bank capital", IMF Staff Discussion Note 16/04

[11] Domeij, D., Flodén, M., (2006) The Labor-Supply Elasticity and Borrowing Constraints: Why Estimates are Biased. Review of Economic Dynamics, 9, 242-262.

[12] Drehmann, M., Juselius, J., (2014), Evaluating early warning indicators of banking crises: Satisfying policy requirements, International Journal of Forecasting, 30 (3), pp. 759-780 
[13] Eggertsson, G., Woodford, M., (2003), "The Zero Bound on Interest Rates and Optimal Monetary Policy," Brookings Papers on Economic Activity, Economic Studies Program, The Brookings Institution, 34(1), pp. 139-235

[14] Eggertsson, G., Mehrotra, N. R., (2014), A Model of Secular Stagnation, No 20574, NBER Working Paper

[15] Hayashi, F., Prescott, E., (2002), The 1990s in Japan: A Lost Decade, Review of Economic Dynamics, 5 (1), pp. 206-235

[16] Iacoviello, M. (2005) "House Prices, Borrowing Constraints and Monetary Policy in the Business Cycle." American Economic Review, 95 (3), 739-764

[17] Iacoviello, M., (2015), Financial Business Cycles, Review of Economic Dynamics, Vol. 18, Issue 1, $140-164$

[18] Iacoviello, M. and Neri, S. (2010), "Housing Market Spillovers: Evidence from an Estimated DSGE Model," American Economic Journal: Macroeconomics, 2, 125-164.

[19] Jorda, O, B Richter, M Schularick and A Taylor (2017): "Bank capital redux: solvency, liquidity, and crisis“, NBER Working Paper no 23287

[20] Krugman, P., (1998), "It's Baaack: Japan's Slump and the Return of the Liquidity Trap," Brookings Papers on Economic Activity, Economic Studies Program, The Brookings Institution, 29 (2), pp. $137-206$

[21] Kydland, F., Prescott, E., (1982). "Time to Build and Aggregate Fluctuations", Econometrica 50 (6), 1345-1370

[22] Korinek, A., Simsek, A., (2016), Liquidity Trap and Excessive Leverage, American Economic Review, 106 (3), pp. 699-738

[23] Laubach, T., Williams, J., (2016), Measuring the Natural Rate of Interest Redux, Business Economics, 51, pp. 257-267

[24] Lawrance, E., (1991), Poverty and the Rate of Time Preference: Evidence from Panel Data, The Journal of Political Economy, 99 (1), 54-77. 
[25] Mendicino, C., Pescatori, A., (2007), Credit Frictions, Housing Prices and Optimal Monetary Policy Rules, mimeo

[26] Rubio, M., Carrasco-Gallego, J. (2016), "The new financial regulation in Basel III and monetary policy: A macroprudential approach," Journal of Financial Stability

[27] Rubio, M., Yao, F., (2019), Macroprudential Policies in a Low Interest-Rate Environment, Journal of Money, Credit and Banking, forthcoming

[28] Smets, F., Wouters, R., (2007), "Shocks and Frictions in US Business Cycles: A Bayesian DSGE Approach," American Economic Review, American Economic Association, 97 (3), pp. 586-606

[29] Werning, I., (2012), Managing a Liquidity Trap: Monetary and Fiscal Policyî, NBER Working Paper 17344 